\title{
madridge
}

\section{Madridge Journal of}

\section{Assessment of Heavy Metalsin Effluent Water Discharges from Textile Industry and River Water at Close Proximity: A Comparison of Two Textile Industries from Funtua and Zaria, North Western Nigeria}

\author{
Oluwaseun E Odipe ${ }^{1}$, Raimi Morufu Olalekan ${ }^{2 \star}$ and Faisal Suleiman ${ }^{1}$ \\ ${ }^{1}$ Department of Environmental Health Sciences, School of Health, Allied and Environmental Science, College of Pure and Applied \\ Sciences, Kwara State University, Malete, Kwara State, Nigeria \\ ${ }^{2}$ Department of Community Medicine, Environmental Health Unit, Faculty of Clinical Sciences, Niger Delta University, Wilberforce \\ Island, Bayelsa State, Nigeria
}

\section{Article Info}

\section{*Corresponding author:} Raimi Morufu Olalekan

Department of Community Medicine Environmental Health Unit Faculty of Clinical Sciences Niger Delta University

Wilberforce Island, Bayelsa State Nigeria

E-mail: ola07038053786@gmail.com; morufu.raimi@waldenu.edu; odipe@yahoo.com

Received: November 11, 2018 Accepted: December 18, 2018

Published: January 2, 2019

\section{Citation: Odipe OE, Raimi MO, Suleiman F. Assessment of Heavy Metals in Effluent Water Discharges from Textile Industry and River Water at Close Proximity: A Comparison of Two Textile Industries from Funtua and Zaria, North Western Nigeria. Madridge J Agric Environ Sci. 2019; 1(1): 1-6. doi: 10.18689/mjaes-1000101}

Copyright: ( $\ 2019$ The Author(s). This work is licensed under a Creative Commons Attribution 4.0 International License, which permits unrestricted use, distribution, and reproduction in any medium, provided the original work is properly cited.

Published by Madridge Publishers

\begin{abstract}
Environmental problems of the textiles industries are mainly cause by the discharge of wastewater coming from the dyeing and finishing processes containing the heavy metals. This study assessed the heavy metals concentrations in the surface water body of neighboring Funtua and Zaria textile industry and effluent water collected from Funtua textile industry using atomic absorption spectrometer (AAS). The concentrations of heavy metals like Lead $(\mathrm{Pb})$, Cadmium $(\mathrm{Cd})$, Iron ( $\mathrm{Fe})$, Zinc $(\mathrm{Zn})$ and Coppernicium $(\mathrm{Cn})$ were assessed and the concentrations of each of the metals varies in the samples collected and analyzed with the following values: Funtua water samples Fe $0.0025 \mathrm{mg} / \mathrm{l}$ lower part and $1.63 \mathrm{mg} / \mathrm{l}$ upper part, Zn 0.51 mg/l lower part and $1.02 \mathrm{mg} / \mathrm{l}$ upper part, $\mathrm{Pb} 0.007 \mathrm{mg} / \mathrm{l}$ lower part and $0.61 \mathrm{mg} / \mathrm{l}$ upper part, $\mathrm{Cd} 0.01 \mathrm{mg} / \mathrm{l}$ lower part and 0.016 upper part, $\mathrm{Cn}$ was not detected (ND), for effluent Fe $3.61 \mathrm{mg} / \mathrm{l}$ and $2.61 \mathrm{mg} / \mathrm{l}, \mathrm{Pb} 2.66 \mathrm{mg} / \mathrm{l}$ and $2.69 \mathrm{mg}, \mathrm{Cd} 0.99 \mathrm{mg} / \mathrm{l}$ and $1.06 \mathrm{mg} / \mathrm{l}$, Zn $2.26 \mathrm{mg} / \mathrm{l}$ and $2.99 \mathrm{mg} / \mathrm{l}, \mathrm{Cn} \mathrm{ND}$ also and for Zaria water samples Fe $0.96 \mathrm{mg} / \mathrm{l}$ lower part and $2.15 \mathrm{mg} / \mathrm{l}$ upper part, Zn $1.07 \mathrm{mg} / \mathrm{l}$ lower part and 1,74 mg/l upper part, $\mathrm{Pb} 0.36 \mathrm{mg} / \mathrm{l}$ lower part and $1.02 \mathrm{mg} / \mathrm{l}$ upper part, $\mathrm{Cd} 0.41 \mathrm{mg} / \mathrm{l}$ lower part and $0.66 \mathrm{mg} / \mathrm{l}$ upper part and $\mathrm{Cn} \mathrm{ND}$ also. Fe and Pb showed concentrations higher than limits set by the NSDWQ and WHO while $\mathrm{Zn}$ and $\mathrm{Cd}$ showed concentrations below limits set by NSDWQ and WHO. The river neighboring Zaria textile happened to be more polluted than the one neighboring Funtua textile industry. It was concluded that the effluent samples of textile industries discharge causes pollution to the water bodies and serious problem for living being and ecological environment. Therefore, the effluent water to be discharged by these industries must be adequately treated before discharge.
\end{abstract}

Keywords: Heavy metal; Effluent; Water; Textiles industries.

\section{Introduction}

Industrial pollution is one of the problems presently facing Nigeria and the world at large while several efforts are being vigorously pursued to control it in various industries spanning length and breadth of the country to see that we live in a disease free environment. Effluent generated by the industries is one of the sources of pollution. Contaminated air, soil, and water by effluents from the industries are associated with heavy disease burden [1] and this could be part of the reasons for the current shorter life expectancy in the country [2] 
when compared to the developed nations. Some heavy metals contained in these effluents (either in free form in the effluents or adsorbed in the suspended solids) from the industries have been found to be carcinogenic [3] while other chemicals equally present are poisonous depending on the dose and exposure duration [4]. These chemicals are not only poisonous to humans but also found toxic to aquatic life [1]. The textile industry is distinguished by raw material used and this determines the volume of water required for production as well as wastewater generated [5].

\section{Objectives of the Study}

The study focused on assessing water quality of water samples at close proximity to the Zaria textile and Funtua textile industry in Northern Nigeria for heavy metal concentration.

\section{Material and Method}

\section{Study area}

The study areas are Funtua textile industry $(\mathrm{FT})$, Zaria textile industry (ZT) and their neighboring river. The Funtua textile is located at Funtua Local Government area of Katsina State and their neighbouring river(s) called "Mairuwa dam" is situated at latitude 11.587657 and longitude 7.238149 (Figure 1). The textile industry was established in 1978. The Local Government lies between latitude $11^{\circ} 32^{\prime} \mathrm{N}$ and longitude $7^{\circ} 19^{\prime} \mathrm{E}$. Similarly, the Zaria textile industry limited is located at old Jos road, Dakace village of Zaria Local Government of Kaduna state. The textile's neighboring river which is popularly known as "Zaria dam" was constructed across the Galma River in 1975. The Zaria Local Government has the population of 975228 people and lies between latitude $114^{\prime} 0.120^{\prime \prime} \mathrm{N}$ and longitude $742^{\prime} 0.000^{\prime \prime} \mathrm{E}$ (Figure 2).

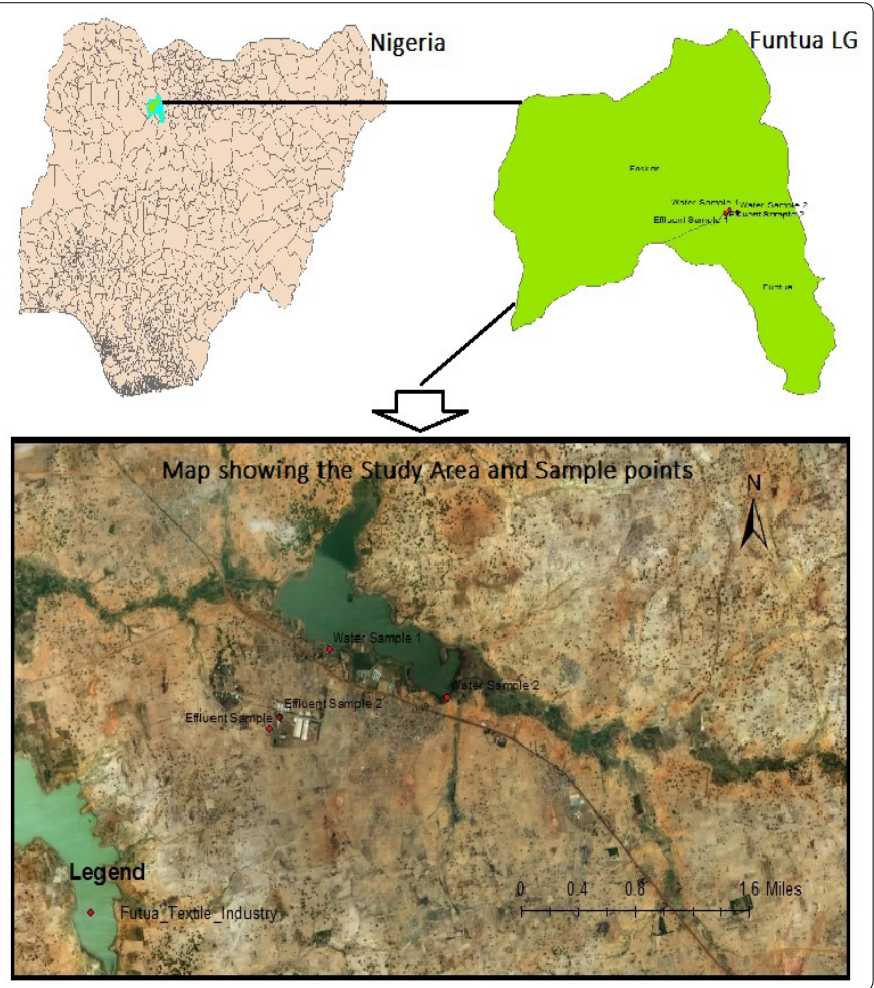

Figure 1. Map of Nigeria showing the Location of the Study Area in Funtua LGA of Katsina Statae.

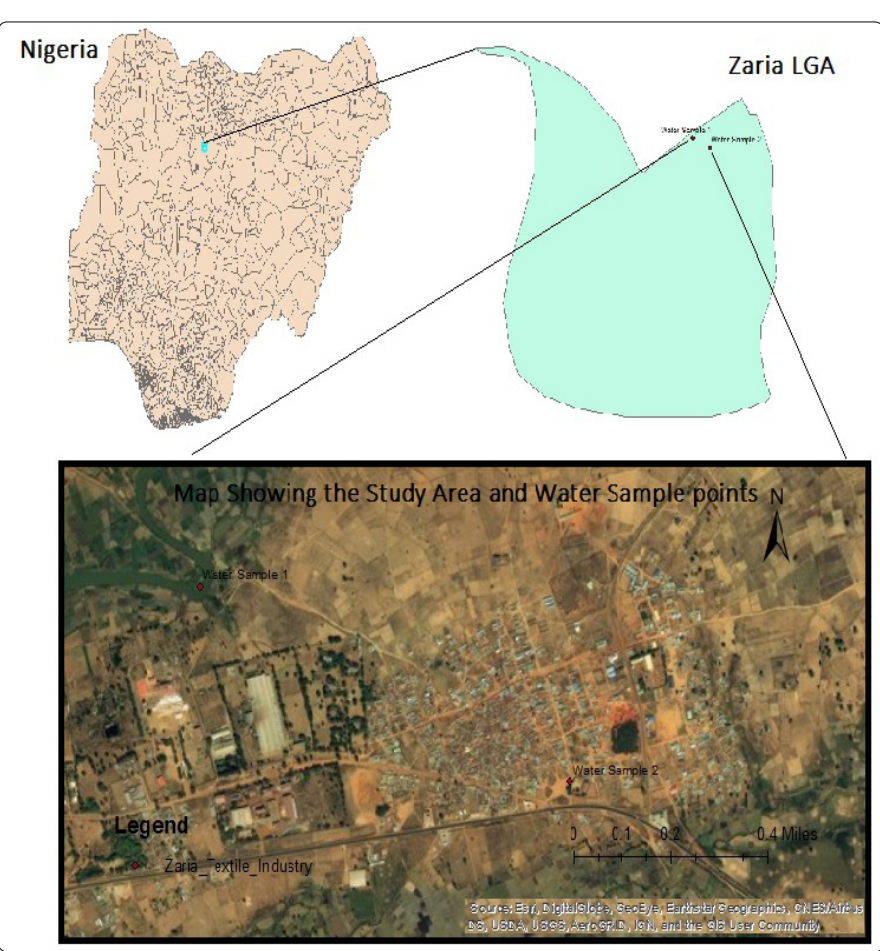

Figure 2. Map of Nigeria showing the Location of the Study Area in Zaria LGA of Kaduna State.

Table 1. Water Samples Coordinates.

\begin{tabular}{|l|c|c|c|}
\hline Sample & Number & Northern & Eastern \\
\hline FT & 1 & $11^{\circ} 34^{\prime} 58.89511^{\prime \prime} \mathrm{N}$ & $7^{\circ} 14^{\prime} 34.38136^{\prime \prime} \mathrm{E}$ \\
\hline FT & 2 & $11^{\circ} 34^{\prime} 43.14515^{\prime \prime} \mathrm{N}$ & $7^{\circ} 15^{\prime} 17.82115^{\prime \prime} \mathrm{E}$ \\
\hline ZT & 3 & $11^{\circ} 5^{\prime} 8.50852^{\prime \prime} \mathrm{N}$ & $7^{\circ} 44^{\prime} 57.90019^{\prime \prime} \mathrm{E}$ \\
\hline ZT & 4 & $11^{\circ} 4^{\prime} 51.612^{\prime \prime} \mathrm{N}$ & $7^{\circ} 45^{\prime} 37.674^{\prime \prime} \mathrm{E}$ \\
\hline
\end{tabular}

Table 2. Effluent Samples Coordinates.

\begin{tabular}{|l|c|c|}
\hline Sample No. & Northern & Eastern \\
\hline 1 & $11^{\circ} 34^{\prime} 33.43879^{\prime \prime} \mathrm{N}$ & $7^{\circ} 14^{\prime} 12.82175^{\prime \prime} \mathrm{E}$ \\
\hline 2 & $11^{\circ} 34^{\prime} 37.49383^{\prime \prime} \mathrm{N}$ & $7^{\circ} 14^{\prime} 16.49908^{\prime \prime} \mathrm{E}$ \\
\hline
\end{tabular}

\section{Sample preservation}

Samples for the heavy metal's analysis were collected in $120 \mathrm{ml}$ plastic container which were initially washed with detergent and rinsed with distilled water. The containers were finally rinsed with $20 \%$ Nitric acid before sampling. The samples were preserved by adding $1.5 \mathrm{ml}$ of conc. $\mathrm{HNO}^{3}$ to each 1 liter of sample and the $\mathrm{pH}$ adjusted to 2.0 by the use of $\mathrm{pH}$ meter. The samples were stored in a refrigerator at about $40^{\circ} \mathrm{C}$, for subsequent analysis. As samples may contain particulate or organic materials, pre treatment in the form of digestion is required before analysis. Nitric acid digestion was employed. The digested sample was taken to laboratory for Atomic Absorption Spectrophotometer (AAS) analysis [6].

\section{Methods of analysis}

Atomic absorption spectroscopy (AAS) determines the presence of metals in liquid samples. Metals determined include $\mathrm{Fe}, \mathrm{Pb}, \mathrm{Cn}, \mathrm{Zn}$, and $\mathrm{Cd}$. It also measures the concentrations of metals in the samples. Typical concentrations range in the low $\mathrm{mg} / \mathrm{L}$ range.

\section{Data analysis}

Data obtained were compared with the Nigeria Standards for Drinking Water Quality [7] and WHO [8] and presented in tabular forms and charts. 


\section{Results and Discussion}

\section{Result}

Table 3. Result of Samples Analyzed Using Atomic Absorption Spectrometer.

\begin{tabular}{|l|c|c|c|c|c|c|}
\hline$M g / l$ & $\begin{array}{c}F T 1 \text { Lower } \\
\text { (A1) }\end{array}$ & $\begin{array}{c}\text { FT2 Upper } \\
\text { (A2) }\end{array}$ & $\begin{array}{c}\text { ZT1 Lower } \\
(B 1)\end{array}$ & $\begin{array}{c}\text { ZT2 Upper } \\
\text { (B2) }\end{array}$ & $\begin{array}{c}\text { Effluent FT } \\
\text { (A) }\end{array}$ & $\begin{array}{c}\text { Effluent FT } \\
(B)\end{array}$ \\
\hline $\mathrm{Fe}$ & 0.025 & 1.63 & 0.96 & 2.15 & 3.61 & 2.61 \\
\hline $\mathrm{Zn}$ & 0.51 & 1.02 & 1.07 & 1.74 & 2.26 & 2.99 \\
\hline $\mathrm{Pb}$ & 0.007 & 0.61 & 0.36 & 1.02 & 2.66 & 2.69 \\
\hline $\mathrm{Cd}$ & 0.01 & 0.016 & 0.41 & 0.66 & 0.99 & 1.06 \\
\hline $\mathrm{Cn}$ & $\mathrm{ND}$ & $\mathrm{ND}$ & $\mathrm{ND}$ & $\mathrm{ND}$ & $\mathrm{ND}$ & $\mathrm{ND}$ \\
\hline
\end{tabular}

ND: Not Detected; FT: Funtua Textile; ZT: Zaria Textile; Effluent ft (a): after discharge; Effluent $\mathrm{ft}(\mathrm{b})$ : before discharge.

Table 4. Nigeria Standard for Drinking Water Quality (NSDWQ, 2013) and WHO (2008) [7-9].

\begin{tabular}{|c|l|c|c|c|}
\hline S/No. & $\begin{array}{l}\text { Parameter/Heavy } \\
\text { metals }\end{array}$ & Unit & $\begin{array}{c}\text { NSDWQ Maximum } \\
\text { permitted limits }\end{array}$ & $\begin{array}{c}\text { WHO Maximum } \\
\text { permitted limits }\end{array}$ \\
\hline 1 & Lead $(\mathrm{Pb})$ & $\mathrm{mg} / \mathrm{l}$ & 0.01 & 0.01 \\
\hline 2 & Zinc $(\mathrm{Zn})$ & $\mathrm{mg} / \mathrm{l}$ & 3 & 3 \\
\hline 3 & Cadmium $(\mathrm{Cd})$ & $\mathrm{mg} / \mathrm{l}$ & 0.003 & 0.003 \\
\hline 4 & Iron $(\mathrm{Fe} 2+)$ & $\mathrm{mg} / \mathrm{l}$ & 0.3 & 0.3 \\
\hline 5 & Copernicium $(\mathrm{Cn})$ & $\mathrm{mg} / \mathrm{l}$ & ----- & ----- \\
\hline
\end{tabular}

\section{Funtua Water samples}

Table 5. Comparison of Funtua Water Samples Analyzed with the NSDWQ [7] and WHO [8].

\begin{tabular}{|l|c|c|c|c|}
\hline Metals & FT1 Lower & FT2 Upper & NSDWQ Mg/l & WHO Mg/l \\
\hline $\mathrm{Fe}$ & 0.0025 & 1.63 & 0.3 & 0.3 \\
\hline $\mathrm{Zn}$ & 0.51 & 1.02 & 3 & 3 \\
\hline $\mathrm{Pb}$ & 0.007 & 0.61 & 0.01 & 0.01 \\
\hline $\mathrm{Cd}$ & 0.01 & 0.016 & 0.003 & 0.003 \\
\hline $\mathrm{Cn}$ & $\mathrm{ND}$ & $\mathrm{ND}$ & $\mathrm{ND}$ & - \\
\hline
\end{tabular}

COMPARISON OF FUNTUA ANALYSED WATER SAMPLES WITH THE NSDWQ, (2013) AND WHO, (2008)

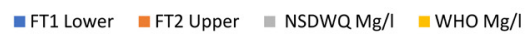

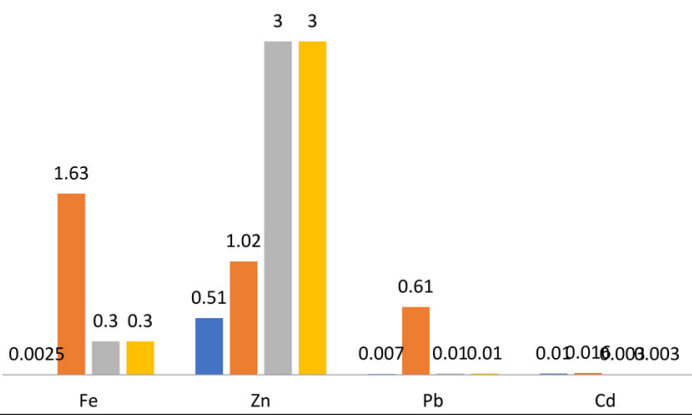

Figure 3. Chart showing comparison of Funtua analyzed water samples with the NSDWQ [7] and WHO [8].

\section{Effluent samples}

Table 6. Comparisons of Funtua Effluent Samples Analyzed with the NSDWQ [7] and WHO [8].

\begin{tabular}{|l|c|c|c|c|}
\hline Metals mg/l & $\begin{array}{c}\text { Effluent FT } \\
(\mathrm{A})\end{array}$ & $\begin{array}{c}\text { Effluent FT } \\
(\mathrm{B})\end{array}$ & $\begin{array}{c}\text { NSDWQ } \\
(\mathbf{2 0 1 3}) \mathrm{Mg} / \mathrm{l}\end{array}$ & WHO (2008) Mg/l \\
\hline $\mathrm{Fe}$ & 3.61 & 2.61 & 0.3 & 0.3 \\
\hline $\mathrm{Zn}$ & 2.26 & 2.99 & 3 & 3 \\
\hline $\mathrm{Pb}$ & 2.66 & 2.69 & 0.01 & 0.01 \\
\hline $\mathrm{Cd}$ & 0.99 & 1.06 & 0.003 & 0.003 \\
\hline $\mathrm{Cn}$ & $\mathrm{ND}$ & $\mathrm{ND}$ & ---- & --- \\
\hline
\end{tabular}

Comparison of Funtua Effluent Samples Analysed with the NSDWQ (2013) and WHO, (2008)

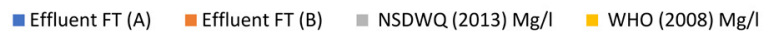

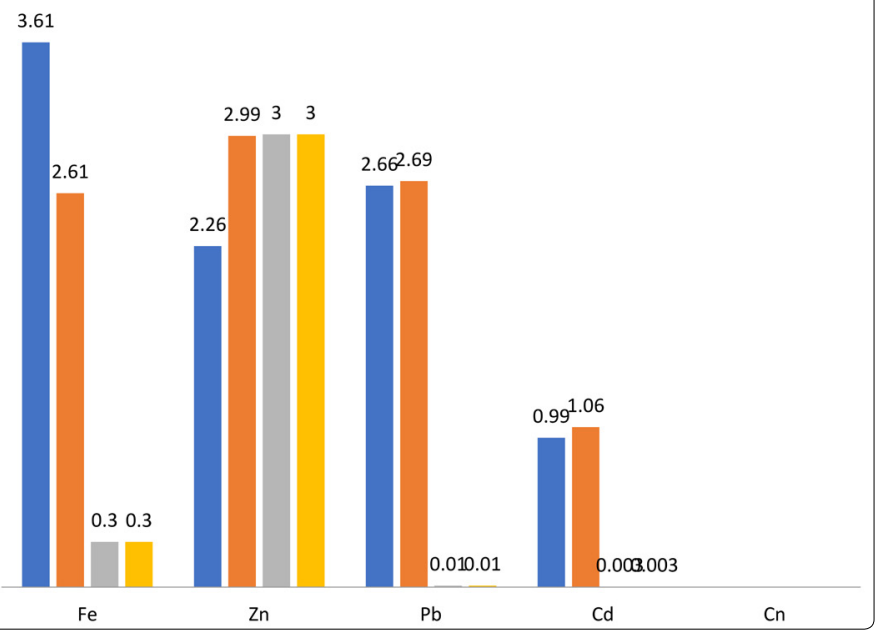

Figure 4. Chart Showing comparison of the Funtua effluent Samples Analyzed Result with the NSDWQ [7] and WHO [8].

\section{Zaria Water samples}

Table 7. Comparison of Zaria Water Samples with the NSDWQ [7] and WHO [8].

\begin{tabular}{|l|c|c|c|c|}
\hline Metals & ZT1 Lower & ZT2 Upper & NSDWQ (2013) Mg/l & WHO (2008) Mg/l \\
\hline Fe & 0.96 & 2.15 & 0.3 & 0.3 \\
\hline $\mathrm{Zn}$ & 1.07 & 1.74 & 3 & 3 \\
\hline $\mathrm{Pb}$ & 0.36 & 1.02 & 0.01 & 0.01 \\
\hline $\mathrm{Cd}$ & 0.41 & 0.66 & 0.003 & 0.003 \\
\hline $\mathrm{Cn}$ & ND & ND & ------ & ------ \\
\hline
\end{tabular}

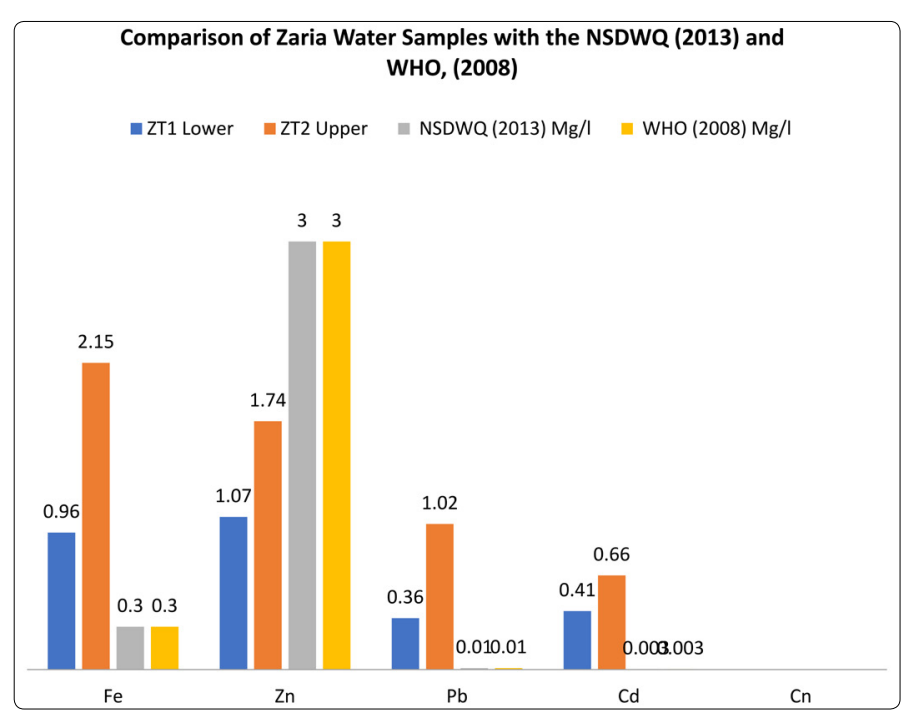

Figure 5. Chart Showing Zaria Water Samples Analyzed with the NSDWQ [7] and WHO [8].

\section{Comparisons}

Table 8. Comparisons of Funtua and Zaria Water Samples with the NSDWQ [7] and WHO [8].

\begin{tabular}{|l|c|c|c|c|c|c|}
\hline $\begin{array}{l}\text { Metals } \\
\mathrm{Mg} / \mathrm{I}\end{array}$ & $\begin{array}{c}\mathrm{FT} 1 \\
\text { Lower }\end{array}$ & $\begin{array}{c}\text { ZT1 } \\
\text { Lower }\end{array}$ & $\begin{array}{c}\text { ZT2 } \\
\text { Upper }\end{array}$ & $\begin{array}{c}\mathrm{FT2} \\
\text { Upper }\end{array}$ & $\begin{array}{c}\text { NSDWQ (2013) } \\
\mathrm{Mg} / \mathrm{l}\end{array}$ & $\begin{array}{c}\mathrm{WHO}(2008) \\
\mathrm{Mg} / \mathrm{l}\end{array}$ \\
\hline $\mathrm{Fe}$ & 0.0025 & 0.96 & 2.15 & 1.63 & 0.3 & 0.3 \\
\hline $\mathrm{Zn}$ & 0.51 & 1.07 & 1.74 & 1.02 & 3 & 3 \\
\hline $\mathrm{Pb}$ & 0.007 & 0.36 & 1.02 & 0.61 & 0.01 & 0.01 \\
\hline $\mathrm{Cd}$ & 0.01 & 0.41 & 0.66 & 0.016 & 0.003 & 0.003 \\
\hline $\mathrm{Cn}$ & $\mathrm{ND}$ & $\mathrm{ND}$ & $\mathrm{ND}$ & $\mathrm{ND}$ & ----- & ----- \\
\hline
\end{tabular}


Comparison of Funtua and Zaria Water Samples Analysed with the WHO,(2008) and NSDWQ, (2013)
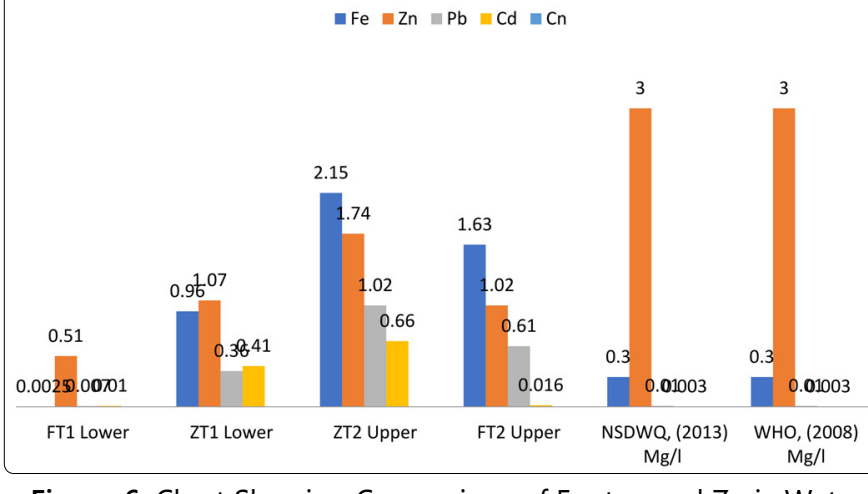

Figure 6. Chart Showing Comparison of Funtua and Zaria Water Samples Analyzed with the WHO [8] and NSDWQ [7].

Table 9. Comparison of Iron (Fe) from each location with NSDWQ [7] and $\mathrm{WHO}[8]$.

\begin{tabular}{|l|c|c|c|c|c|c|}
\hline $\begin{array}{l}\text { Metals } \\
\mathrm{Mg} / \mathrm{l}\end{array}$ & $\begin{array}{c}\mathrm{FT} 1 \\
\text { Lower }\end{array}$ & $\begin{array}{c}\text { ZT1 } \\
\text { Lower }\end{array}$ & $\begin{array}{c}\text { ZT2 } \\
\text { Upper }\end{array}$ & $\begin{array}{c}\mathrm{FT} 2 \\
\text { Upper }\end{array}$ & $\begin{array}{c}\text { NSDWQ, (2013) } \\
\mathrm{Mg} / \mathrm{l}\end{array}$ & $\begin{array}{c}\text { WHO, (2008) } \\
\mathrm{Mg} / \mathrm{l}\end{array}$ \\
\hline $\mathrm{Fe}$ & 0.0025 & 0.96 & 2.15 & 1.63 & 0.3 & 0.3 \\
\hline
\end{tabular}

\section{Fe}

$=\mathrm{Fe}$

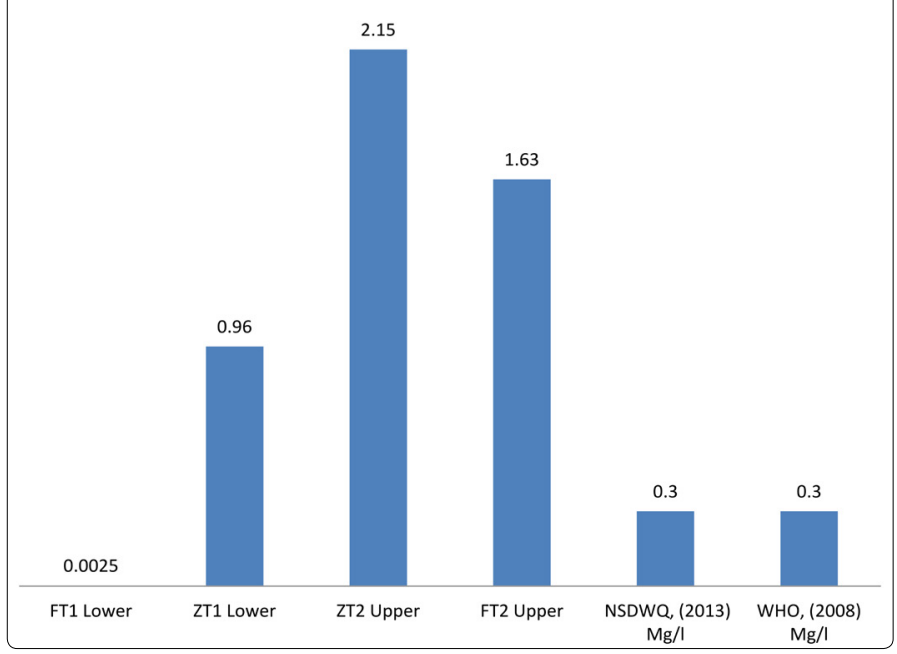

Figure 7. Chart Showing Comparisons of Fe Concentration found from the Analyzed Samples of both Funtua and Zaria with the Standards.

Table 10. Comparisons of Zinc (Zn) Concentration found from the Analyzed Samples of both Funtua and Zaria with the Standards.

\begin{tabular}{|l|c|c|c|c|c|c|}
\hline $\begin{array}{l}\text { Metals } \\
\text { Mg/l }\end{array}$ & $\begin{array}{c}\text { FT1 } \\
\text { Lower }\end{array}$ & $\begin{array}{c}\text { ZT1 } \\
\text { Lower }\end{array}$ & $\begin{array}{c}\text { ZT2 } \\
\text { Upper }\end{array}$ & $\begin{array}{c}\text { FT2 } \\
\text { Upper }\end{array}$ & $\begin{array}{c}\text { NSDWQ (2013) } \\
\text { Mg/l }\end{array}$ & $\begin{array}{c}\text { WHO (2008) } \\
\text { Mg/l }\end{array}$ \\
\hline $\mathrm{Zn}$ & 0.51 & 1.07 & 1.74 & 1.02 & 3 & 3 \\
\hline
\end{tabular}

Table 11. Comparisons of $\mathrm{Pb}$ Concentration found from the Analyzed Samples of both Funtua and Zaria with the Standards specified by NSDWQ [7] and WHO [8] Standards.

\begin{tabular}{|l|c|c|c|c|c|c|}
\hline $\begin{array}{l}\text { Metals } \\
\mathrm{Mg} / \mathrm{l}\end{array}$ & $\begin{array}{c}\mathrm{FT} 1 \\
\text { Lower }\end{array}$ & $\begin{array}{c}\text { ZT1 } \\
\text { Lower }\end{array}$ & $\begin{array}{c}\text { ZT2 } \\
\text { Upper }\end{array}$ & $\begin{array}{c}\mathrm{FT2} \\
\text { Upper }\end{array}$ & $\begin{array}{c}\text { NSDWQ (2013) } \\
\mathrm{Mg} / \mathrm{l}\end{array}$ & $\begin{array}{c}\text { WHO (2008) } \\
\mathrm{Mg} / \mathrm{l}\end{array}$ \\
\hline $\mathrm{Pb}$ & 0.007 & 0.36 & 1.02 & 0.61 & 0.01 & 0.01 \\
\hline
\end{tabular}

Table 12. Comparisons of $\mathrm{Cd}$ Concentration found from the Analyzed Samples of both Funtua and Zaria with the NSDWQ [7] and WHO [8] Standards.

\begin{tabular}{|l|c|c|c|c|c|c|}
\hline $\begin{array}{l}\text { Metals } \\
\text { Mg/l }\end{array}$ & $\begin{array}{c}\text { FT1 } \\
\text { Lower }\end{array}$ & $\begin{array}{c}\text { ZT1 } \\
\text { Lower }\end{array}$ & $\begin{array}{c}\text { ZT2 } \\
\text { Upper }\end{array}$ & $\begin{array}{c}\text { FT2 } \\
\text { Upper }\end{array}$ & $\begin{array}{c}\text { NSDWQ (2013) } \\
\text { Mg/l }\end{array}$ & $\begin{array}{c}\text { WHO (2008) } \\
\text { Mg/l }\end{array}$ \\
\hline Cd & 0.01 & 0.41 & 0.66 & 0.016 & 0.003 & 0.003 \\
\hline
\end{tabular}

\section{Discussion FUNTUA}

Funtua water samples: In the water sample neighboring Funtua textile industry analyzed using atomic absorption spectroscopy Fe was found to have concentrations of $0.0025 \mathrm{mg} / \mathrm{l}$ from the lower part of the river which is relatively lower than NSDWQ [7] and $\mathrm{WHO}$ [8] of $0.3 \mathrm{mg} / \mathrm{l}$ and concentrations of $1.63 \mathrm{mg} / \mathrm{l}$ from the upper part which is higher than NSDWQ [7] and WHO [8]. Other heavy metals have the following concentrations.

Zn: $0.51 \mathrm{mg} / \mathrm{from}$ the lower part while $1.02 \mathrm{mg} / \mathrm{l}$ from the upper part and both from the lower and the upper of the river the concentrations of $\mathrm{Zn}$ are lower than NSDWQ [7] and WHO [8] of $3 \mathrm{mg} /$.

Pb: $0.007 \mathrm{mg} / \mathrm{l}$ from the lower part which is lower than the NSDWQ [7] and WHO [8] of $0.01 \mathrm{mg} / \mathrm{l}$ while $0.61 \mathrm{mg} / \mathrm{l}$ from the upper part and this is higher than NSDWQ [7] and WHO [8].

Cd: $0.01 \mathrm{mg} / \mathrm{l}$ from the lower part and concentrations of 0.016 $\mathrm{mg} / \mathrm{l}$ from the upper part and both are higher than NSDWQ [7] and WHO [8] of $0.003 \mathrm{mg} / \mathrm{l}$.

Cn: this metal was not detected in the samples analyzed.

\section{Funtua effluent water samples}

The effluent water samples analyzed has the following concentrations Fe $3.61 \mathrm{mg} / \mathrm{l}$ and $2.61 \mathrm{mg} / \mathrm{l}, \mathrm{Pb} 2.66 \mathrm{mg} / \mathrm{l}$ and $2.69 \mathrm{mg} / \mathrm{l}, \mathrm{Cd} 0.99 \mathrm{mg} / \mathrm{l}$ and $1.06 \mathrm{mg} / \mathrm{l}$ and all these are higher than NSDWQ [7] and WHO [8] of Fe $0.3 \mathrm{mg} / \mathrm{l}, \mathrm{Pb} 0.01 \mathrm{mg} / \mathrm{l}, \mathrm{Cd}$ $0.003 \mathrm{mg} / \mathrm{l}$. while $\mathrm{Zn}$ have the concentrations of $2.26 \mathrm{mg} / \mathrm{l}$ and $2.99 \mathrm{mg} / \mathrm{l}$ which are lower than threshold limit specified by the NSDWQ [7] and WHO [8] respectively. And Cn was not detected in the entire effluent samples analyzed.

\section{ZARIA}

\section{Zaria Water Samples}

For the water sample neighboring Zaria textiles industry collected and analyzed Fe was found to have concentrations of $0.96 \mathrm{mg} / \mathrm{l}$ from the lower part and $2.15 \mathrm{mg} / \mathrm{l}$ from the upper part and all has the concentrations higher than NSDWQ [7] and WHO [8] of $0.3 \mathrm{mg} / \mathrm{l}$. other heavy metals have following concentrations.

Zn: $1.07 \mathrm{mg} / \mathrm{l}$ from the lower part and $1.74 \mathrm{mg} / \mathrm{l}$ from the upper part which all have concentrations lower than that specified by the NSDWQ [7] and WHO [8] of $3 \mathrm{mg} / \mathrm{l}$.

Pb: $0.36 \mathrm{mg} / \mathrm{l}$ from the lower part and $1.02 \mathrm{mg} / \mathrm{l}$ from the upper part and these concentrations are higher than NSDWQ [7] and WHO [8] of $0.01 \mathrm{mg} / \mathrm{l}$.

Cd: $0.41 \mathrm{mg} / \mathrm{l}$ from the lower part and $0.66 \mathrm{mg} / \mathrm{l}$ from the upper part which are higher than the NSDWQ [7] and WHO [8] of $0.003 \mathrm{mg} / \mathrm{l}$.

Cn: this heavy metal was also not detected from the entire samples analyzed.

\section{Comparison of Each Element with their Locations and the NSDWQ [7] and WHO [8]}

Iron (Fe) for Funtua water samples analyzed was found to have concentrations of $0.0025 \mathrm{mg} / \mathrm{l}$ from the lower part of the 
river which is relatively lower than NSDWQ [7] and WHO [8] of $0.3 \mathrm{mg} / \mathrm{l}$ and concentrations of $1.63 \mathrm{mg} / \mathrm{l}$ from the upper part which is higher than NSDWQ [7] and WHO [8]. While in Zaria water samples was found to have concentrations of $0.96 \mathrm{mg} / \mathrm{l}$ from the lower part and $2.15 \mathrm{mg} / \mathrm{l}$ from the upper part and all has the concentrations higher than NSDWQ [7] and WHO [8] of $0.3 \mathrm{mg} / \mathrm{l}$ as shown in figure 8 .

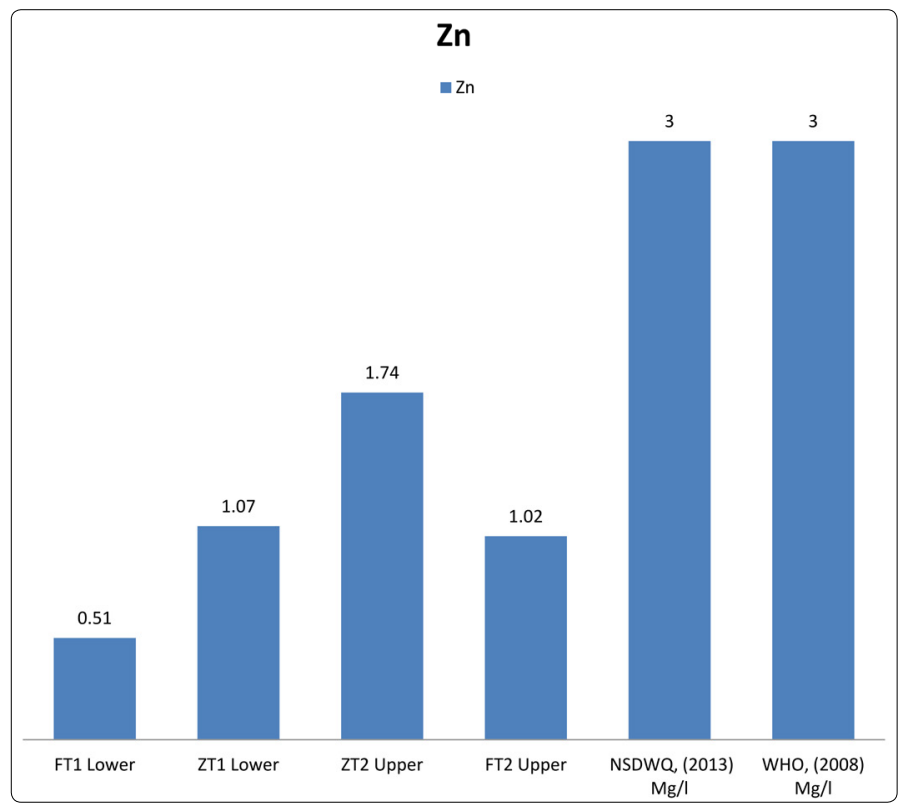

Figure 8. Chart Showing Comparisons of Zn Concentration found from the Analyzed Samples of both Funtua and Zaria with the Standards.

Zinc (Zn) for Funtua $0.51 \mathrm{mg} / \mathrm{l}$ from the lower part while 1.02 $\mathrm{mg} / \mathrm{l}$ from the upper part and both from the lower and the upper of the river the concentrations of $\mathrm{Zn}$ are lower than NSDWQ [7] and WHO [8] of $3 \mathrm{mg} / \mathrm{l}$. While $1.07 \mathrm{mg} / \mathrm{l}$ from the lower part and $1.74 \mathrm{mg} / \mathrm{l}$ from the upper part which all have concentrations lower than that specified by the NSDWQ [7] and $\mathrm{WHO}$ [8] of $3 \mathrm{mg} / \mathrm{l}$ for Zaria water samples analyzed as shown in figure 9.

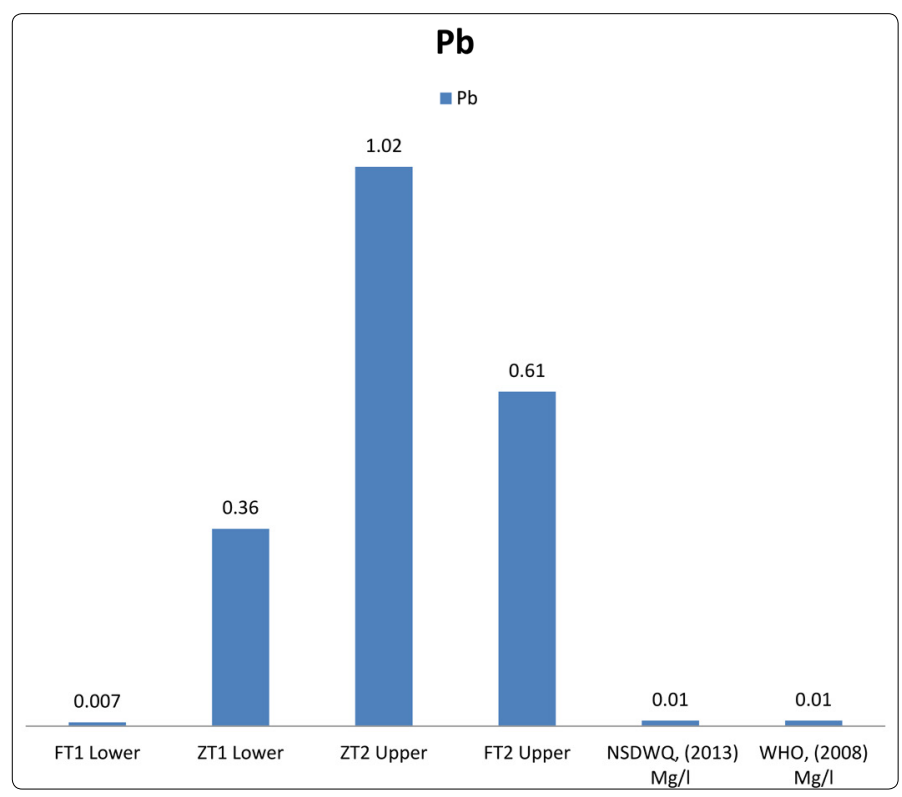

Figure 9. Chart Showing Comparisons of $\mathrm{Pb}$ Concentration found from the Analyzed Samples of both Funtua and Zaria with the Standards with the Standards.
Lead (Pb) for Funtua $0.007 \mathrm{mg} / \mathrm{l}$ from the lower part which is lower than the NSDWQ [7] and WHO [8] of $0.01 \mathrm{mg} / \mathrm{l}$ while $0.61 \mathrm{mg} / \mathrm{l}$ from the upper part and this is higher than NSDWQ [7] and WHO [8]. While these concentrations of $0.36 \mathrm{mg} / \mathrm{l}$ from the lower part and $1.02 \mathrm{mg} / \mathrm{l}$ from the upper part are higher than NSDWQ [7] and WHO [8] of $0.01 \mathrm{mg} / \mathrm{l}$ for Zaria water samples that are analyzed as shown in figure 10.

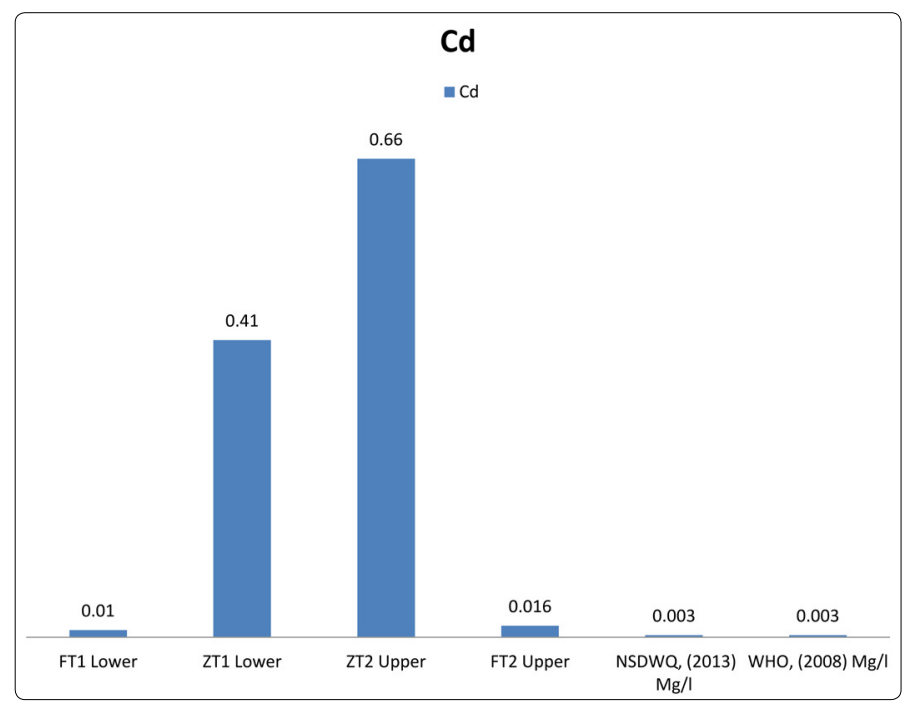

Figure 10. Chart Showing Comparisons of Cd Concentration found from the Analyzed Samples of both Funtua and Zaria with the Standards.

Cadmium Cd for Funtua $0.01 \mathrm{mg} / \mathrm{l}$ from the lower part and concentrations of $0.016 \mathrm{mg} / \mathrm{l}$ from the upper part and both are higher than NSDWQ [7] and WHO [8] of $0.003 \mathrm{mg} / \mathrm{l}$. While $0.41 \mathrm{mg} / \mathrm{l}$ from the lower part and $0.66 \mathrm{mg} / \mathrm{l}$ from the upper part which are higher than the NSDWQ [7] and WHO [8] of $0.003 \mathrm{mg} / \mathrm{l}$ for Zaria water samples analyzed (Figure 10).

Coppernicium (Cn) this was not detected in the entire samples analyzed.

\section{Inference}

As shown in figures 6-10, the river neighboring Zaria textile industry happened to be more polluted than the river neighboring Funtua textile industry. And this showed the level of effluent water treatment undergone by Funtua textile before discharges to be more reasonable and higher/lower concentration level of heavy metals than that of Zaria textile industry although Zaria textile's effluent was not gotten.

There is a need for adequate treatment of effluent water before discharge in to the environment and water bodies as well as adequate treatment of the water sources to appropriate quality before uses as these concentrations could result in severe damage of the body organs over varying periods of consumption times.

\section{Conclusion}

The discharge of Funtua and Zaria textile industry's effluent water into neighboring water bodies invariably result in the presence of high concentrations of pollutants (heavy metals) in the water. The Fe has been shown to be present in concentrations higher than the NSDWQ [7] in the upper part of the river neighboring Funtua textile industry which showed 
the lower part to be safer than the upper part and this is because it is close to the textile effluent discharging channel, $\mathrm{Zn}$ was found to be present in concentrations lower than NSDWQ [7] from both the upper and the lower part of the river which showed the water to be safe from $\mathrm{Zn}$ toxicity, $\mathrm{Pb}$ was found to be present in concentrations higher than the standards from the upper part and in concentrations lower than NSDWQ [7] in the lower part which showed the lower part to be safer than the lower part, $\mathrm{Cd}$ with concentrations above NSDWQ [7] from both lower and the upper part and $C n$ was not detected which showed the river to be safe from $\mathrm{Cd}$ and $\mathrm{Cn}$. While for water samples neighboring Zaria textile industry Fe was found to be present in concentrations higher than NSDWQ [7] in both the upper and lower part, Zn was found to be present in concentrations lower than NSDWQ [7] in both the upper and the lower part of the rivers, $\mathrm{Pb}$ and $\mathrm{Cd}$ was found to be present in concentrations higher than NSDWQ [7] in both the lower parts and the upper parts of the rivers which both parts are not safe, and $\mathrm{Cn}$ was not detected in the entire sample analyzed. As shown in the figures 3 and 5 the upper parts of both the Funtua and Zaria happened to be more polluted than the lower parts. The effluents also have considerable negative effects on the water quality of the neighboring water bodies and as such, they are rendered not good for human use without adequate treatment.

\section{Recommendations}

1. All textile industries should avoid the use of metallic dyes in their dying process which are possibly the sources of the heavy metals in the effluent and water discharges.

2. Textiles industries should adopt the use of "Air Dying Technology" as the process uses air instead of water to dye garments, designs and color without polluting the water and the environment.

3. All effluent water should be adequately treated to render it safe before discharge in to the environment and the neighboring water bodies.

4. Imposition of direct charges on industrial effluents by the regulating agency.

5. Continuous monitoring and surveillance is imperative in order to ensure the protection of water resources from degradation.

\section{References}

1. WHO. Water Pollutants: Biological Agents, Dissolved Chemicals, Nondissolved Chemicals, Sediments, Heat. WHO CEHA. Amman, Jordan. 2002.

2. WHO. The World Health Report 2003: Shaping the Future. World Health Organization. 1211 Geneva 27, Switzerland. 2003.

3. Tamburlini G, Ehrenstein OV, Bertollini R. Children's Health and Environment: A Review of Evidence. In: Environmental Issue Report No.129. WHO/European Environment Agency, WHO Geneva. 2002: 223.

4. Kupechella CE, Hyland MC. Environmental Science Living within the System of Nature. Allyn and Baron, London. 1989

5. Yusuff RO, Sonibare JA. Characterization of textile industries' effluents in Kaduna, Nigeria and pollution implications. Global Nest: Int J. 2004; 6(3): 212-221.

6. Sperling WM. Atomic Absorption Spectrometry. Wiley-VCH. Weinheim, Germany, ISBN 3-527-28571-7. 1999.

7. Nigerian Industrial Standard. Nigerian Standard for Drinking Water Quality. Standards Organisation of Nigeria. 2007; 554: 29.

8. World Health Organization. Guidelines for drinking-water quality: second addendum. Volume 1, Recommendations, $3^{\text {rd }}$ Edition. World Health Organization. 2008.

9. Al Nouri D, Al Abdulkarim B, Arzoo S, Nabi Bakeet ZA. Quality characteristics of commonly consumed drinking water in Riyadh and effect of domestic treatments on its chemical constituents. J Food Nutr Res. 2014; 2(1): 25-33. 